\title{
Northern Ireland: twenty years of troubled peace
}

\author{
David Mitchell \\ Assistant Professor of Conflict Resolution and Reconciliation \\ Trinity College Dublin at Belfast \\ damitche@tcd.ie
}

Current History, 117: 797, 89 - 95.

March 2018

April 2018 marks twenty years since Northern Ireland's 'Good Friday' or 'Belfast' Agreement. The political and security reforms set out in this document were designed to bring political stability to a region which had experienced thirty years of anti-state and inter-communal bloodshed, a conflict normally referred to as 'the Troubles'. The leaders of the opposing ethno-political blocs received the 1998 Nobel Peace Prize and Northern Ireland, so long synonymous with urban violence and political unrest, was rebranded as a peacemaking paragon. However, as the twentieth anniversary inevitably prompts reflection on the legacy of the Agreement, a contradictory picture presents itself.

On the one hand, the indicators are remarkably positive. Political violence is rare, tourist numbers are soaring, and central Belfast increasingly resembles a 'normal', prosperous European city. The international desire for learning from Northern Ireland continues, with a steady flow of personnel between Ireland and conflict zones around the world engaged in sharing experiences and expertise in conflict resolution. On the other hand, the 1998 Agreement may be under unprecedented threat. The collapse of power-sharing in early 2017, the prospect of collateral damage from Brexit, and the ongoing failure to implement transitional justice measures to 'deal with the past', combine to raise serious questions about the sustainability of governance as envisaged by the Agreement, as well as Northern Ireland's reputation as a 'model' peace. 
British political involvement in Ireland dates back to 1169 , but the origins of the modern conflict in Northern Ireland are usually traced to the 'Plantations' of the sixteenth and seventeenth centuries. This was a settler-colonial project of the English Crown, and religious difference proved to be of preeminent importance. The new creed of the settlers - Protestantism and especially the strict Calvinism of the Scots - precluded intermarriage and assimilation, flavoured a particular view of the world and the native Irish, and maintained a distinctive pattern of separation. In the nineteenth century, Protestant-dominated Belfast became a world-leading industrial city. The region's burgeoning prosperity and economic productivity cemented Ulster Protestants' political attachment to Britain and its empire, and were internalised as evidence of their own cultural advancement, ingenuity and work ethic.

Hence virulent Protestant opposition to the emerging Irish push for autonomy from Britain the 'Home Rule' campaign which gathered strength in the late nineteenth century. This period saw the divisions rooted in earlier centuries of settlement crystallise into two modern nationalist movements, secular in aim, but often religious in their expression and self-understanding. One was Protestant, 'unionist', and centred in the north of the island, and the other Catholic, 'nationalist', and centred on Dublin. The intensifying hostility of these two movements led the British to divide the island in 1920.

For London, partition was a tool of political expediency aimed at avoiding civil war. To Irish republicans, it was a colonial carve-up which unnaturally disfigured the island into two parts so that Britain, aided by its settler-client population, the unionists, could retain a power foothold in the North. The Protestant unionists also wished to maintain Irish unity within the United Kingdom but they acquiesced to the arrangement as the best guarantee of their economic security and what they saw as their 'Protestant way of life'. For them, the border expressed a political, social and economic division that already existed between North and South. 
But if partition pacified the immediate situation, it created problems for the future. The location of the border created a new configuration of majorities and minorities: thousands of northern Protestants were 'abandoned' in the southern state, while one third of the inhabitants of Northern Ireland were Catholic and, broadly, Irish nationalist. The two new political entities fell into a cold war of suspicion, developing dichotomous religious and cultural identities. The unionists operated a de facto one-party state, with Catholics discriminated against in public employment, security policy, housing, and other areas.

The stasis was shattered in the late 1960s. Inspired by campaigns in the United States and Europe, a new and ambitious generation of Catholics (and some Protestants) organised street marches to demand civil rights. These were interpreted by many Protestants as attempts to destroy Northern Ireland and were met by a repressive response - by security forces and Protestant gangs. In the course of the spiralling unrest, the Irish Republican Army (IRA), a semi-dormant militant nationalist group, was reactivated and exploited the heady climate to begin an insurrection aimed at removing British rule from the North and re-uniting the island. Protestant paramilitaries emerged to fight the IRA. In the hope of containing the emergency, the British took over direct political and security control of Northern Ireland in 1972, but repeated attempts to re-establish local control on a basis that both nationalists and unionists could accept failed. Between 1969 and 1998, among a population of one and a half million, 3627 people were killed and tens of thousands injured, traumatised, and displaced.

For the peace process that emerged in the early 1990s, some credit has been afforded to geopolitical shifts: peace developments in South Africa and Palestine in the early 1990s, and the end of the Cold War. However, two processes closer to home were most salient. One was intensified cooperation between the British and Irish states on reaching a political solution in Northern Ireland. This partnership was institutionalised in the Anglo-Irish Agreement of 1985. Mutual membership of the European Union (EU) facilitated contact between politicians and civil servants and enhanced the 
standing of the Irish vis-à-vis the British, undermining the asymmetry of the historic colonial relationship. The EU also offered a model of trans-national relations and a fresh discourse on sovereignty, identity and borders that helped reframe how the states understood themselves and their territorial conflict. John Hume, for one, leader of the moderate nationalist Social Democratic and Labour Party (SDLP) and a key architect of the peace process, was well known for incessantly citing Europe as an inspirational example of what was possible in Ireland

The other catalytic process was the realisation of the Northern Ireland parties that indefinitely pursuing uncompromising ends was impossible. The increasing success of the security forces in foiling IRA attacks showed republicans that continuing armed action indefinitely would prolong the hardship of their community and likely yield few political rewards. Accordingly, republicans - who became a major electoral force during the 1980s through their political party Sinn Féin - were open to the offer of Government-sponsored negotiations. For their part, unionists were inclined to negotiate for two reasons. Firstly, they disliked Direct Rule from London and they despised the Anglo-Irish Agreement which gave Dublin a consultative role in Northern Irish affairs. The return of devolved government to Northern Ireland would remove both problems but the British would only permit this to happen on the basis of cross-community power-sharing. Secondly, unionists feared that if they stonewalled, London might pursue policies that would be even less agreeable to unionists such as joint British-Irish authority over Northern Ireland.

As the peace process took shape, contact between political actors facilitated by track-two diplomacy, back-channel dialogue, and the work of reconciliation groups, and the forums of political talks and conferences, helped foster a sense of mutual purpose. On all sides, there was a desire to spare future generations from what 'the Troubles' generation had lived through. Trust was more elusive, yet there emerged a clear desire to create the conditions - the institutions and atmosphere - in which cross-party trust could be built. Eventually, the impulse to co-operation came to fruition in the Good Friday Agreement. 
The centrepiece of the Agreement was a power-sharing Assembly within Northern Ireland. An Executive Committee of Ministers, open to all parties of sufficient strength, would be presided over by a First Minister and Deputy First Minster who would be elected by a cross-community vote. Relations between Northern Ireland and the Republic of Ireland would be addressed primarily through a North-South Ministerial Council (NSMC), a forum comprising ministers from the Assembly and the Irish Government tasked to agree policies in a range of areas of mutual, mainly economic and cultural, interest. The NSMC would be 'balanced' by an east-west institution, the British-Irish Council, involving ministers from the Irish Government and the various UK jurisdictions. Regarding the constitutional status of Northern Ireland, talks participants accepted the 'principle of consent': that that status should be decided by the will of a majority within Northern Ireland. This meant British sovereignty would continue but the rule allowed Irish nationalists to keep alive their hopes of Irish unity in the future. The Agreement emphatically recognised the identity, ethos and aspirations of unionists and nationalists as equally legitimate, but it also endorsed a third option: 'the birthright of all the people of Northern Ireland to identify themselves and be accepted as Irish or British, or both'. In this way, the Agreement attempted to detach identity from territory and sovereignty and transform the zero-sum clash of identities at the heart of the conflict.

But agreeing and implementing these institutional provisions proved to be considerably more straightforward than aspects of the Agreement pertaining to the legacy of violence. A particularly contentious question was what to do with paramilitary weapons. The Agreement sidestepped the issue, leaving it unclear whether paramilitary-linked parties could join the new government before their military-wings destroyed the arms which had so recently been used to kill and intimidate. Meanwhile, the Agreement permitted the release of paramilitary prisoners, again without any pre-condition of disarmament, while also providing for significant reforms of the police 
force. This was a nationalist demand, but an offense to unionists who rejected the claim that the Royal Ulster Constabulary had been anything other than an impartial bulwark against terrorist anarchy during 'the Troubles'.

Overall, parties to the conflict held contradictory interpretations of the deal. Moderate Irish nationalists and the British and Irish states hailed the Agreement as an historic compromise which had the potential to bring an end to Protestant-Catholic and British-Irish antagonism. Republicans, somewhat equivocally, accepted the Agreement, arguing that it allowed them to continue to pursue their goal of a united Ireland. A minority of republicans viewed it as a defeat and a betrayal, and continued a low-level campaign of violence. Unionists split almost evenly. The Ulster Unionist Party (UUP) leadership supported it, primarily because it maintained UK sovereignty, but a conservative faction, along with the hard-line Democratic Unionist Party (DUP), opposed the Agreement, rejecting what they saw as its political and moral compromises. Given all these points of contention, the successful implementation of the Agreement was far from certain.

As it turned out, implementation was tumultuous, dogged by crises, electoral shifts and street unrest. In 2018, some of the obstacles to peace implementation that were known in 1998 are history. Others remain. The issue of paramilitary weapons was the greatest stumbling block, delaying stable power-sharing for nine years. Weapons took on a moral and symbolic resonance out of proportion with their practical significance i.e. even if weapons were destroyed, paramilitaries could always acquire more. The matter led to a straightforward standoff between unionists - who saw IRA weapons decommissioning as necessary tangible evidence of republicans' commitment to peaceful means - and Sinn Féin - which was determined to avoid the appearance of republican surrender, and which wanted evidence that the unionists were genuinely committed to partnership and equality with Catholics. Unionists did share power for periods in 1999-2002 on condition that IRA decommissioning occur ('No guns, no government', was unionists' interpretation and mantra), but 
government eventually collapsed, while the unionist electorate's frustration led to the victory of the right-wing DUP over the UUP in elections in 2003.

Eventually, due to pressure from the American and Irish Governments and republicans' own calculation of what was required for their political and electoral advancement, the IRA decommissioned its weapons in 2005. This totemic move paved the way for the resumption of power-sharing, this time, between the former extreme parties, the DUP and Sinn Féin. On the 8 May 2007, the public witnessed the unthinkable: Ian Paisley, fundamentalist Protestant church leader and DUP leader, taking office as First Minister, and Martin McGuinness, former IRA commander, becoming Deputy First Minister, all amidst an atmosphere of good-humour, sincerity and hope. Thus began an extraordinary political partnership and, by all accounts, genuine friendship, between the erstwhile enemies - a kind of relationship that has not been evident between any of Paisley and McGuinness's successors.

While decommissioning was resolved, contestation over cultural and symbolic expression continues. Too difficult to resolve in the talks, the Agreement merely made a vague call for 'sensitivity' in the display of flags and emblems. Numerous disputes over the public display of symbols occurred, but by far the most intense surrounded the decision by Belfast City Council in December 2012 to reduce the number of days the British flag flew from City Hall. This precipitated weeks of riots and street protests by unionists. For them, the decision was indicative of unionist decline and a republican 'culture war' waged against all expressions of Britishness and unionism in Northern Ireland. This period also spotlighted the ongoing malaise of working-class Protestant communities, blighted by unemployment and educational underachievement, and disillusioned with the peace process and the unionist political class.

The flag dispute hinged on the question of whether Northern Ireland was a purely British part of the UK, or whether the diversity of national aspirations within the region (regardless of the reality of full British sovereignty there) should impact on the visible expressions of the state. This 
question was also at the heart of the indefinite cessation of power-sharing in 2017. The initial cause (unusually for Northern Ireland) had nothing to do conflict politics, but a financial scandal. Sinn Féin left the government in protest over the DUP's handling of a renewable heating incentive scheme. However, Martin McGuinness, at that stage suffering from an illness that would months later prove to be terminal, made clear in his resignation letter that there were other reasons why his party could not continue in a political relationship with the DUP, in particular, the latter's blocking of legislation to protect and promote the Irish language.

While few people speak Irish as their everyday language, the language has immense symbolic value as a marker of Irish national identity. For some Northern Catholics, state-supported expressions of the language would constitute a meaningful indicator of equality of treatment in a region which has been traditionally hostile to Irish culture. Unionists oppose an Irish Language Act for several reasons, but above all, because they believe (not incorrectly) that Sinn Féin view it means to reduce the British character of Northern Ireland and ultimately hasten Irish unity. At the time of writing the stand-off over a Language Act is unresolved.

A further post-Agreement challenge, ongoing, has been how to 'deal with the past' i.e. address the legacy of countless acts of violence during 'the Troubles' for which no-one has been brought to justice. Should the state continue to investigate and seek prosecutions? Should a line be drawn under the past and people just move on? How should victims be cared for, and does the category of 'victim' include those who were also perpetrators? A measure of consensus was reached on these issues in the Stormont House Agreement of 2014 when the parties agreed to a package of mechanisms that would allow for information retrieval, prosecutions where possible and desired, and an oral history archive. These, however, remain unimplemented. Ultimately, 'dealing with the past' is shorthand for addressing the fact that the conflict ended without agreement on why it started. The Agreement did not (could not) apportion blame or victory, or provide an agreed account of the causes of the conflict. Hence, since 1998, parties have sought vindication in how the 
Agreement has been implemented - whether the various implementation crises and dilemmas have played out in a pro-unionist or pro-nationalist manner.

Part of this contest is rooted in the constitutional provisions of the Agreement - the principle of consent. Since this principle allows for a united Ireland in the future if a majority so wishes, many in Northern Ireland have calculated that dealing with the past really means dealing with the future, and that any ground given on the past is a zero-sum loss that only assists the other side in pursuing its constitutional ideal. In other words, exposure of the state's role in violently repressing the Catholic community supports republican arguments that Northern Ireland has always been unjust and artificial. Exposure of the sectarianism of the IRA bolsters unionist arguments that Sinn Féin continues to work from a warped analysis which denies the strength and legitimacy of the unionist presence in Ireland. In this view, victories on the past boost morale in the present and enhance the odds for the future. It remains an open question whether power-sharing can operate successfully and with sufficient mutual trust when each main party holds diametrically opposed aspirations for the future of the region.

Into this already challenging scenario arrived Brexit. During the Brexit referendum campaign, the potential threat to the peace process was stressed by 'remainers'; Tony Blair, and his predecessor as British Prime Minister, John Major, campaigned together to highlight this issue, as did local parties. The threat was not that violence would re-erupt. The threat was that the stability of the fledgling and hard-won modes of governance in Northern Ireland would be undermined. A central purpose of the Agreement was to enhance Northern Catholics' sense of being at ease in Northern Ireland, and this was to be achieved in part through closer North-South relations. The most tangible and psychologically powerful manifestation of this rapprochement was the removal of all security infrastructure at the border, rendering invisible what was technically an international divide. Now, with the UK leaving the EU, this most porous of borders will become, for the first time, an EU 
frontier, raising the prospect of a 'hard border' that would both disrupt the free movement of people and goods, and re-draw a border in the minds of the people of the island.

All sides have been emphatic that they wish to avoid the return of a hard border, and in December 2017, the British and the EU, with the support of the Irish Government and the Northern Ireland parties, reached an agreement of principles that whatever the ultimate outcome of the Brexit talks, a border would not be reintroduced in Ireland and the Good Friday Agreement would be protected. This calmed fears but whether and how this communiqué would be implemented remained dependent on the outcome of the subsequent phases of negotiations. It is also unlikely that this agreement will end debate about Brexit's impact on the very existence of the UK as currently constituted.

Northern nationalists - a majority of whom have been content with the post-1998 dispensation in Northern Ireland and whom overwhelmingly support the EU - may begin to see a united Ireland, not merely as a long term or emotional aspiration, but a real and immediate goal. Even some moderate unionists may find what they regard as a progressive and internationalist Republic of Ireland preferable over an insular and British nationalist UK. Sinn Féin, naturally, wishes to test all this in a referendum on Irish unity. It is beyond ironic that what is potentially the greatest step towards a united Ireland since 1998 - Brexit's impact on opinion in Ireland - had little to do with Sinn Féin or any Irish separatist group, but anti-EU English nationalists.

At the same time, Brexit could lead to pro-EU Scotland's departure from the UK, a development that would render even more precarious Northern Ireland's place in the Union. The only main Northern Ireland party to enthusiastically support Brexit is the DUP, ideological kin of the right-wing of the British Conservative Party. The strong potential for Brexit to energise Irish and Scottish nationalism to the detriment of the unity of the UK makes the DUP's stance a potential own goal. In June 2017, the DUP agreed to prop up Theresa May's government in Westminster, her party shrunken after an election which she had thought would have the opposite effect. This alliance 
flies in the face of the recent convention that London acts as a neutral honest broker in relation to the North of Ireland. It adds to a sense that British-Irish politics has entered disorienting new waters and that the peace process is adrift.

Meanwhile, as Brexit occupies London and Dublin and politics in Belfast has ground to a halt, on the streets and in the countryside of Northern Ireland, the reality of a society divided persists. Segregation is most tangibly represented by the 'peace walls', physical barriers between Protestant and Catholic areas. Their purpose is to prevent houses being attacked but their impact is to prevent contact between the communities. Sporadic street rioting occurs, often connected to parades by the Orange Order, a Protestant politico-cultural organisation. Northern Ireland has a system of de facto segregated education, with most pupils attending schools which are predominantly Protestant or Catholic. Over ninety per cent of social housing is overwhelming Protestant or Catholic. Most people live, are educated, play sport, worship, and socialise, in singleidentity settings.

The conflict has also left a legacy in the power of paramilitary groups, still holding a mafiastyle grip on many impoverished urban areas. They engage in organised crime and mete out 'justice' through brutal beatings and shootings. 'Dissident' republicans who opposed the peace process carry on a campaign of violence directed mainly at the police and prison officers. Other social divides are increasingly visible. Race hate attacks are frequent. Same-sex marriage and abortion law are hotly contested as campaigners push for liberalisation. Patriarchal structures and culture - expressed and sharpened through the violent conflict - survive and women remain underrepresented in most sectors of society.

Despite the myriad challenges, there are reasons to be optimistic. The key pillars of the 1998 accord - the principle of consent, power-sharing, North-South institutions - are more widely accepted now than twenty years ago. Catholic exclusion is over. Most significantly, republicanism has stayed firmly on its path away from violence, and this has helped reconcile the vast majority of 
unionism to co-operation with former enemies. Prior to Brexit, the relationship of Britain and Ireland was at its closest ever, consolidated by hugely symbolic and successful visits of members of the British royal family to the Republic. Yes, society is divided and politics unstable. These realities are attributed by some critics to the 'consociational' nature of the Agreement which arguably consolidates and rewards the opposing ethnic blocs and forces them to share power without sharing a vision for the region. Yet it could be countered that the survival of a functioning (just about) power-sharing government for ten years from 2007-2017 was nothing short of miraculous. Many facets of division, including the fear and prejudice which still fill hearts and minds, will unavoidably take generations to erode.

People in Northern Ireland tend to be well aware of the imperfections of the peace. But observers from conflict zones around the world continue to be drawn to the Northern Ireland case as proof that intractable conflict can be transformed, however slow, halting and messy is that process. The challenges that Northern Ireland faces in 2018 are considerable yet greater obstacles were surmounted at earlier stages in the peace process. As ever, with sufficient will and imagination on the part of its people and political leadership, Northern Ireland can continue on the path set out in the 1998 Agreement: towards stability, interdependence, and reconciliation. 